\title{
Island brands and 'the Island' as a brand: insights from immigrant entrepreneurs on Prince Edward Island
}

\author{
Godfrey Baldacchino \\ University of Prince Edward Island \\ 550 University Avenue, Charlottetown \\ PE, C1A 4P3, Canada \\ E-mail: gbaldacchino@upei.ca
}

\begin{abstract}
How well do the brands and branding exercises of specific 'island products' connect with the brand of 'the Island' on which they are based? This paper adopts a sweeping 'island studies' global perspective in addressing this question. Given that they are already heavily themed places, we should not be surprised to find that islands typically brand themselves with a view to appeal to actual and potential visitors; in so doing, they invariably neglect, render indistinct or discount the appeal of the quality of their island life. Data sets from a 2004 survey of locally owned European small island businesses, as well as from a 2008 study of immigrant entrepreneurs on Prince Edward Island (PEI), Canada, suggest that quality of life features are a key component of the island allure - rather than a concoction tailored for alien consumption. Such features are more likely to attract and retain 'lifestyle entrepreneurs', are more likely to fit comfortably with the vision that the islanders may have about themselves, but will become increasingly problematic in the long term if they are successful in attracting many more immigrants to 'the Island'.
\end{abstract}

Keywords: island; island as brand; entrepreneurship; small business; Prince Edward Island; PEI; brand consolidation; quality of life.

Reference to this paper should be made as follows: Baldacchino, G. (2010) 'Island brands and 'the Island' as a brand: insights from immigrant entrepreneurs on Prince Edward Island', Int. J. Entrepreneurship and Small Business, Vol. 9, No. 4, pp.378-393.

Biographical notes: Godfrey Baldacchino is Professor and Canada Research Chair in Island Studies at the University of Prince Edward Island, Canada, and a Visiting Professor of Sociology, University of Malta, Malta. He is the Executive Editor of Island Studies Journal, a Director of the Global Islands Network, a founding member of the Islands Commission of the International Geographical Union, executive member of the International Small Islands Studies Association and a member of the international editorial/advisory boards of five scholarly journals. He has authored or edited 30 books and monographs, and has penned over 70 peer-reviewed journal articles or book chapters. His latest books include Extreme Tourism: Lessons from the World's Cold Water Islands (2006), Bridging Islands: The Impact of Fixed Links (2007) and A World of Islands: An Island Studies Reader (2007). He was the academic director of a European Union-funded project that examined the conditions for successful small-scale manufacturing in five European island regions. He has served as a Visiting Professor to tertiary education institutions in Barbados, Canada, Fiji, Iceland, Mauritius and the Seychelles. 


\section{Introduction}

\section{1 'The Island' as a brand}

I was recently asked to join some colleagues and participate in a brainstorming session with a view to determine an appropriate tag line or positioning statement that would serve as a slogan and logo (slogo) for my employer, the University of Prince Edward Island. We wanted a term that was verbal shorthand for something valued and distinct; but it needed to both capture the safe, nurturing and intimate atmosphere and 'sense of place' of the Prince Edward Island (PEI) community, as well as suggesting that it was a place for dynamism, creative energy and discovery. We did bounce off a few ideas - including 'Place Matters', 'Think and Thwim', 'Roots and Routes' - but we were not fully convinced or excited by any of them. As one of the few universities in the world where the island location is part of the title, we concluded that perhaps the 'Island' in the name is enough: in its vagueness, it may say it all. The University of Prince Edward Island is its own sound bite.

After all, one needs to acknowledge that the word 'island' is one of the most heavily romanced, certainly in the English language. Along with the forest, the seashore and the valley, the island is a natural environment “... that has figured prominently in humanity's dreams of the ideal world" (Tuan, 1990, p.247). The association with mystery, fantasy, redemption, paradise and refuge is a long-lasting one that continues to be exploited by global media (such as Fantasy Island, Blue Lagoon, Castaway, Lost ...), literature (such as the Robinsonnade genre, starting with Robinson Crusoe, then Swiss Family Robinson, The Mysterious Island ...), and the global tourism industry. Islands suggest themselves as empty spaces, waiting and wanting to be possessed and tinkered with. They enjoy a lingering 'charm', 'lure' and 'fascination' (Baum, 1996; Baum, 2000; King, 1993; Weale, 1992, p.93), ideally suited to tempt and taunt visitors desirous of refreshment, salvation or reinvigoration. The island is so thoroughly seeped in 'emotional geography' (e.g., Stratford, 2008) that it is perhaps impossible to disentangle its 'realities' from its 'dreams' (Royle, 2001, Chap. 1), its geographical materiality from its metaphorical allusions.

And so, islands have been branded long before the concept found its way into management schools and contemporary marketing discourse. Already in the 10th century, Eric the Red, an early settler on a large and remote island, is reported in old Icelandic sagas to have named that new territory Greenland in order to attract other settlers there. Five hundred years ago, it was claimed that one could harvest cod from Newfoundland waters simply by lowering a basket into the sea. Perhaps we can consider islands as prototypes, targets for some of the earliest systematic attempts at branding: advancing, and romancing, a meaningful and desirable difference in a world crowded by competitive categories (Martin, 1989, p.201).

\section{Layout}

This paper will explore some of the implications of developing and nurturing island-based product brands in association with the tenet of a contextual, all-encompassing 'Island brand'. The objective is to assess the ability to craft a robust image for a particular island jurisdiction that supports, and is supported by, its own 
products and services. Such 'brand consolidation' (e.g., Knudsen et al., 1997) can be extremely effective because it provides consistent market signals and an accumulation of shared experiences across product or service categories. It offers an opportunity to rationalise marketing costs and support profitable brand growth and expansion. However, brand consolidation also risks alienating loyal users, and confusing actual or potential patrons. Especially pertinent to this paper is the dilemma of carrying forward what appear to be valued and mature but diverse images and 'tropes' within the same Island brand, particularly those for nature-based/driven versus technology-based/driven products. These arguments will be fleshed in the context of PEI, Canada's smallest and only totally enisled province. A dataset of 48 immigrant entrepreneurs on PEI - along with select interview material from this rubric - will be appraised in order to generate a better understanding of the differences, if any, in the manner of interpreting 'the Island allure' between entrepreneurs with nature-based and driven businesses and those who offer products/services that are more technologically/IT oriented.

\section{Economic versus ecologic island development}

Many successful island jurisdictions today find themselves operating within one of two distinct development paradigms. The first is typified by dynamic, aggressive and competitive export producers who can depend on strong knowledge and finance capital pools. Such locations typically have high population densities, limited land areas, large pools of immigrant labour, considerable foreign direct investment, significant manufacturing sectors and extensive overseas investments, but poor and degraded local natural environments (if any exist) and higher per capita carbon footprints. 'City states' such as Hong Kong, Malta, Monaco and Singapore - as well as larger countries such as Japan - are leading examples (e.g., Debattista, 2007). These would have usurped the 'slowcoach of agriculture', given the absence or low political clout of a rural hinterland (Streeten, 1993, p.199). In contrast, the second is typified by locales that flaunt their clean, serene and pristine natural environments. Low population densities help maintain this more sustainable lifestyle, which in turn promotes a nature friendly, tourism industry. Dominica, Seychelles, Samoa, Tobago, Greenland, New Zealand and the Faroes are examples (National Geographic, 2006). What does one do, however, if a particular island wants to be successful on both these fronts? Can one be both economically and ecologically successful, and be known globally for both? How have island states such as Ireland and Iceland (e.g., The Economist, 2006) managed to portray themselves as 'smart' (technologically savvy), without sacrificing their representation as places where nature is bountiful, where whiskey can coexist with cloning research (as in Scotland), and where quality milk chocolate can coexist with precision watches (as in Switzerland)? Can an island be both green and clever at the same time? ${ }^{1}$

This is certainly not an easy task. One difficulty arises because of keen contestation over the use of land - an obviously finite resource on islands, especially smaller islands. Tasmania, for example, although a relatively large island, continues to struggle to define itself with considerable interests intent on commercially exploiting its forests, while other interests, equally but differently considerable, are determined to protect and preserve them. The environmental cost associated with building an aluminium smelter in Eastern 
Iceland has divided that island's population (Hollingham, 2007). A second difficulty arises in terms of investment policy choices: are precious public funds - grants, loans, subsidies, incentives, tax breaks, risk capital provision - to be distributed across the board, and thus risking dilution; or should one or a few flagship sectors, or clusters of excellence be identified, at the risk of alienating and angering other constituencies... all of whom are likely to be uncomfortably close to, and intimate with, their politicians (e.g., Debono, 2007; Hirczy, 1995)? A third is that, if symbolic embodiments are not validated and reinforced by actual consumer experiences, the whole exercise may lose credibility and become suspect as sham. Fourthly, if the obligation to create and embrace associations and expectations from a range of products and/or services is simply too diverse and broad, the personality of the brand can suffer erosion and adulteration. Finally, if an island is already deeply wedded to an existing, iconic image typically connected to some locally available species, craft or material with high levels of local input (such as Fair Isle sweaters, Guernsey cows, Shetland ponies, Texel sheep, Barbados rum, Gozo cheese, Cyprus Brandy, Trinidad hot sauce), how does it connect with a more contemporary, dynamic, technologically oriented symbolism without forfeiting its existing baggage, when the latter is likely to have persisting and long-term benefits in terms of reputation, customer loyalty and international recognition? Is it too ambitious to want to have one's cake and eat it too?

This is a dilemma that is shared by many economies, including those on small islands. In the NISSOS Project, which examined successful, small scale, export oriented, locally owned manufacturing firms from six island jurisdictions in Europe, such firms would have deftly fallen within one of these two product categories: one that is obviously nature based and driven (natural craft and natural agricultural products); the other with higher levels of technological input (chemical, plastic, IT and engineering based) - see Table 1; also NISSOS website (2007). In the case of Iceland, the number of high-tech products far overshadows those that are associated more with nature: a clear indication of the high labour costs and rather poor state of the indigenous agricultural industry in that challenging climate and terrain. In the case of Saaremaa, the situation is reversed, since that Estonian county is still an emerging economy with competitive labour costs and a still under-sophisticated technological platform. The situation in Åland, Malta and Scottish Isles is more mixed: the evidence 'on the ground' suggests some difficulty in how to position one's Island brand, lest the pursuit of imaging that may be beneficial to some industries may end up damaging others at the same time. Population density suggests that Malta's economic future may include some sophisticated manufacturing; whereas Åland and such Scottish Isles as Skye and Shetland remain blessed by diverse, 'green' natural assets. 


\begin{tabular}{|c|c|c|c|c|c|}
\hline Island territory & No. of firms & Natural craft & Natural agro & Chemical/Plastic & IT/Hi-tech/Engineering \\
\hline \multirow[t]{3}{*}{ Åland Islands } & 25 & Wood panels & Meat processing & Sausage skins & Purifier units \\
\hline & & Furniture & Fish processing & Air cleaning systems & Welding/Electrical systems \\
\hline & & Sheet-metal (9) & Sour apples (7) & Plastic printing (5) & IT/Software (4) \\
\hline \multirow[t]{5}{*}{ Iceland } & 42 & & Cod/Shark liver oil & Sulphur resistant pipes & Artificial intelligence games \\
\hline & & & Cattle food & Plastic tubs/Fishing nets & Anti-virus software \\
\hline & & & Candy & Fibreglass boats & Electrical equipment \\
\hline & & & Poultry processing & Fish scales (9) & Fish industry equipment \\
\hline & & & Fish processing (20) & & $\begin{array}{l}\text { Digital } \\
\text { electro-encephalograms (13) }\end{array}$ \\
\hline \multirow[t]{4}{*}{ Malta } & 33 & Decorative glass/Lace & Olive oil & Plastic pipes/Cables & IT packages \\
\hline & & Gold/Silver filigree & Wine/Sausages & Paints/Detergents & Software support \\
\hline & & Furniture (6) & Sun-dried tomatoes & Labels/Packaging & Solar panels (6) \\
\hline & & & Liqueurs (6) & Injection moulding (15) & \\
\hline \multirow[t]{4}{*}{ Saaremaa } & 19 & Lime/Agar/Limestone & Fish processing & Rubber products (2) & Aluminium boats (2) \\
\hline & & Wooden houses & Berry processing & & \\
\hline & & Wooden boats (8) & Meat processing & & \\
\hline & & & Fur products (7) & & \\
\hline \multirow[t]{4}{*}{ Scottish Isles } & 25 & Stone & Preserves & Toiletries/Soaps (2) & Electrical instruments \\
\hline & & Woollen knits/Drums/Fabrics & Smoked salmon & & Flexible circuits \\
\hline & & Jewellery/Furniture & Whisky & & Observation devices \\
\hline & & Pottery/Furniture (12) & Beer (7) & & Transformers (4) \\
\hline
\end{tabular}

Note: Number of actual firms in brackets.

Sources: NISSOS Project and Baldacchino (2005a, Table 2) 


\section{Enter PEI: the green province}

'Green' is also markedly evident in the predicament of PEI, Canada's smallest of ten provinces, an island of some $5656 \mathrm{~km}^{2}$ in land area and a resident population of some 138000 . The island's claim to fame rests on three distinct and unrelated episodes, each of which has been recognised and celebrated on a PEI vehicle licence template:

1 'the Birthplace of Confederation', remindful of the historic meeting that took place in 1864 in Charlottetown (the provincial capital) and which eventually led to the establishment of Canada

2 the context for the endearing Anne of Green Gables book series by Lucy Maud Montgomery, probably PEI's most famous islander

3 the 14-km long Confederation Bridge, an engineering marvel which has linked the island to the Canadian mainland since 1997.

As far as branding is concerned, the island is known as 'Spud Isle' and 'the million acre farm' for its potato production; its working country-scapes are sought for and lauded by over a million tourists annually. The rolling fields of 'the Island', and modest investments in wind energy, have collectively contributed to the promotion of the place as 'The Green Province', following a branding exercise in 2006. The slogan is now on the current PEI vehicle licence template, and is accompanied by a section of red soil on which is perched a solitary wind turbine. Meanwhile, the powerful tourism industry, not to be outdone, undertook its own visioning campaign, and developed the sound bite 'The Gentle Island' (In French: La Douceur de l'Île); these are the phrases that introduce the province's current tourism brochures and other publicity material (e.g., http://mygentleisland.com/).

But how well does 'The Gentle Island' or 'The Green Province' work for PEI? That there is more than just one clear, official statement of what the Island purports to be already muddies the waters. And for a province that recently unveiled a Cdn $\$ 200$ million 'prosperity strategy' that rests on four 'innovative sectors' - biosciences, information technology, aerospace and energy (Government of PEI, 2008) - the notion of 'the gentle island' does not fit so comfortably. PEI wants to be 'up and running', and not just a laid back location of calm, indolence and a dolce far niente: good for attracting frazzled tourists wishing to unwind on the beach, but little else.

To come to grips with the 'economic versus ecologic' development choices for Prince Edward Island, this paper refers to data collated from a project Profiling Immigrant Entrepreneurs (PIE) on PEI. The idea is to examine this cross-section of the business community more closely, with a view to determine more clearly whether and how the two 'eco principles' (after Dahl, 1996) can coexist and co-benefit from an island-wide positioning exercise. The 'PIE Project' was supported by the Population Secretariat of the PEI Provincial Government in order to develop a collation of stories from the Island's current stock of immigrant entrepreneurs - with their own opinions about what made them come, stay, and open their business on PEI. At least 48 different immigrant entrepreneurs have been identified and interviewed in this research-in-progress (Baldacchino and McAndrew Fall, 2008). As with Table 1 above, these businesspersons can be categorised by number and economic sector, and they fall neatly within four inter-related 'activity clusters' as identified in Figure 1. 
Figure 1 Schematic location of immigrant businesses in the Prince Edward Island economy (2008) (see online version for colours)

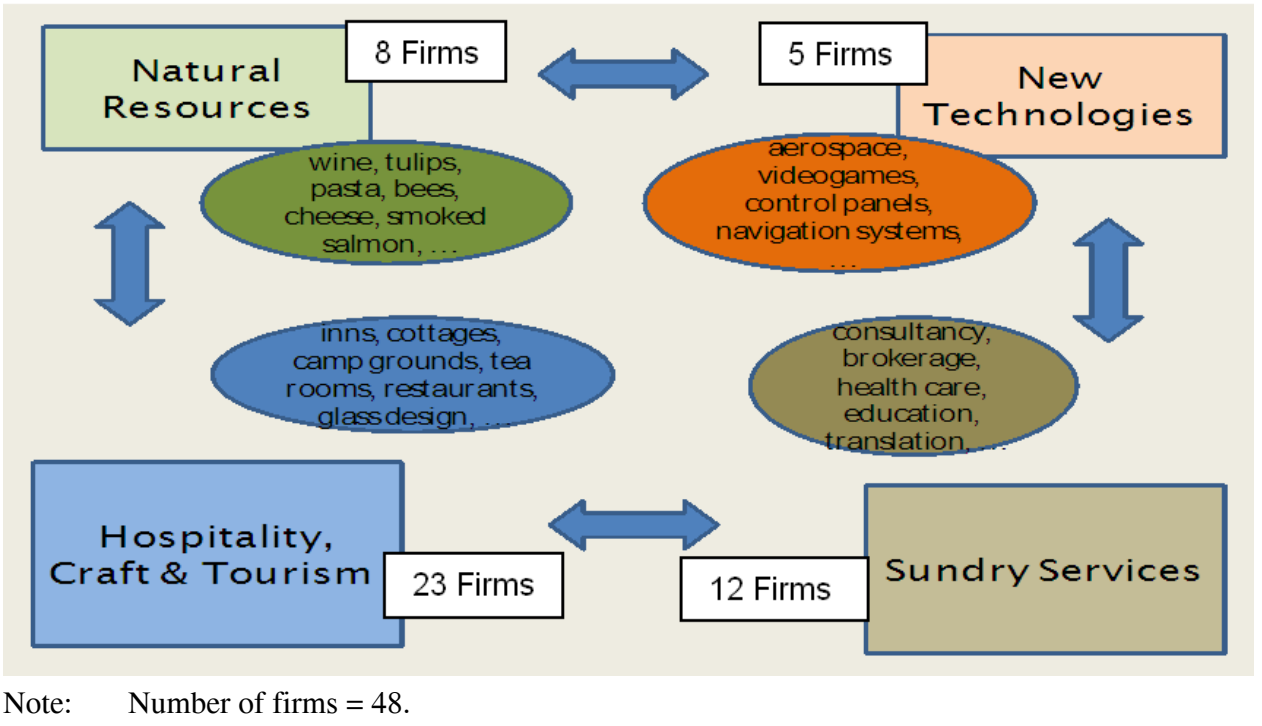

Amongst these groupings, those in the largest sub-category (23 firms) have invested in accommodation related services - from quaint bed and breakfasts to full-scale inns and hotels - plus the (related) catering trade: themed and ethnic restaurants, representing the culinary traditions of at least eight different countries. There is then a motley range of providers of craft products or professional, consulting and brokerage services - from architectural design to carpentry, from translation services to healthcare, from private tuition to glass ceramics (12 firms). Next come the farmers, vintners, flower growers, cheese makers, salmon and eel smokers who have developed premier food and beverage items - sourced mainly with local raw material - for the discerning client (eight firms). Finally, the latest generation of new business ventures is driven by young, well educated, and more technologically savvy entrepreneurs. Their interests are in computer gaming, automation, aerospace and navigation instruments (five firms).

The businesses set up and run by immigrant entrepreneurs on PEI provide an interesting commentary on the nature of the Island economy as a whole. These immigrant businesspersons partake in an enduring love affair with the land and its resources: mainly by branching out into wholesome, gourmet foods and wines. There is investment in the tourism sector, and the vibrant hospitality and craft sectors that latch onto this, providing premier accommodation and dining experiences, as well as novelty local souvenirs. Then, there is also a significant critical mass of innovative investment based on new information, communication, entertainment and energy related technologies. All complemented with a sprinkling of other small scale, professional and service activities which have developed by identifying expertise gaps in the local market.

These niches are not mutually exclusive: those running cafés source local foods; those producing fine foods target tourists as customers. However, there do appear to be less upstream or downstream linkages between the modern, knowledge driven sector and all the others. Does this observation contour our understanding of PEI in the 21 st century as both an 'intelligent' island, and a 'gentle' one? 


\section{Routes to immigrant entrepreneurship}

Why do immigrants become entrepreneurs? The 48 profiled immigrant entrepreneurs currently active on PEI suggest at least three answers to this burning question. First, self-employment may be a necessary route, often a default option after failing to secure suitable waged employment. Second, it may simply be a carryover of entrepreneurship already practised in the country of origin. Third, it may be a course of action following a conscious and well-thought out decision, in which case location is as (if not more) important than the actual product or service being offered (see Figure 2).

Figure 2 Routes to immigrant entrepreneurship to PEI (2008) (see online version for colours)

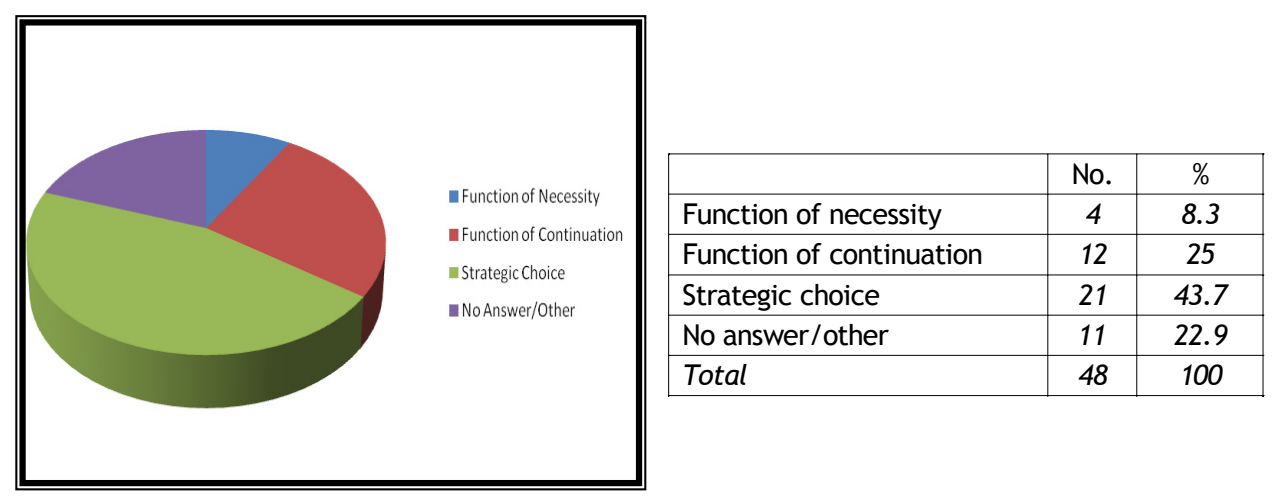

\subsection{Entrepreneurship as function of continuation}

An important remark to make with respect to entrepreneurs - and immigrant entrepreneurs in particular - is that they do not necessarily become entrepreneurs as a conscious and deliberate choice. Of course, various entrepreneurs already had a flourishing business prior to their migration. In such cases, they simply recreated the material conditions to resume their production or service delivery on PEI:

The Romany Rest is a small 4-star, country farmhouse operating as an ensuite B\&B, complete with outdoor swimming pool, since October 2006. Before coming to PEI, owners Sandra and Fred Storr lived in a 'tiny Welsh village in the mountains', raising sheep and operating a small shop and café that promoted local produce; some of which they grew themselves.

In 2002, Robert and Jane Manning still owned and operated a hotel in England; but the constant demands of their work were much more than they desired. Once their three sons were old enough to choose their own futures, Robert and Jane settled on Prince Edward Island.

\subsection{Entrepreneurship as function of necessity}

For others, the status of entrepreneur may have been one that they were forced to adopt and maintain because of the loss of a previous job or the inability to source suitable employment. Necessity, apart from 'the need to achieve' (McClelland, 1987, p.222), becomes the mother of invention: in such cases, even the nature of entrepreneurship may be instructive. In the case of PEI with its relatively inexpensive property (the cheapest in 
Canada per unit area ${ }^{2}$ ) and still rather underdeveloped ethnic food scene, one should not be surprised to find so many immigrant entrepreneurs engaged in either accommodation or catering activities; each of these sectors requires relatively lower amounts of start up capital and limited business expertise. Both of these sets of activities can easily engage and depend on domestic labour, thus cutting operating expenditures:

Martina ter Beek (a Dutch Immigrant to PEI) had a heritage of cheese-making through her grandparents. Gouda cheese production began in her kitchen with homemade, rather primitive tools constructed of whatever utensils were available. In time, she was able to import, through the generosity of her family in Holland, a mould to shape the cheese and a large bucket for processing. With some milk from her own cows, a few homemade tools, and a lot of determination, in 1988, Martina began to make fine Gouda cheese.

In the year 2000, Chien Ming and Kuo Yeh (Taiwanese Immigrants) moved to PEI after five years in Ontario. They were out of work, and with just $\$ 10,000$ in the bank. "And so, we decided to open a shop; but, what kind of shop? Then I remembered that all my family members work in the tea house business, so I decide to open a tea house". In 2003, the Yehs were encouraged to buy a larger store. Chien's parents agreed to lend them $\$ 75,000$ and to migrate to PEI in order to help run the new operation, the Formosa Tea House, which was duly inaugurated in 2004.

Italo Marzari (an Italian immigrant) moved to Prince Edward Island to become an instructor at the respected culinary institute in Charlottetown. When a downturn in the economy occurred, Italo was faced with two options: move off the Island or create his own employment. The outcome of this decision is as authentic an Italian restaurant as you can get: he opened Sirenella Ristorante in 1992.

\subsection{Entrepreneurship as strategic choice}

Is the motivation for entrepreneurship amongst those individuals who have settled down on PEI and opened hi-tech and/or knowledge driven businesses any different from that of these two categories? The data suggests that those behind technology-driven firms certainly have a more strategic rationale for deciding to set up their business in a specific (in this case island) location. Theirs is a well-thought out combination of pull factors (which include fiscal incentives; strong work ethic; the availability and cost of a competitive, well educated and English speaking workforce; and 'quality of life' matters such as tempo, security and neighbourliness) and push factors (which include the stress of long commutes, crime, anonymity and other features of life in 'the big city'):

Kevan Merson is a Scottish design engineer and entrepreneur from Aberdeen, Scotland. He and his family vacationed on Prince Edward Island in 1998; an experience that led him back year after year. In time, a home on Panmure Island was constructed because "We fell in love with PEI," explains Kevan. MarineNav Ltd. was established on Panmure Island in 2005 as an R\&D company that manufactures and markets its own highly sophisticated on-board computer systems used for vessel management, monitoring, and navigation... According to Kevan, choosing to settle in a rather remote forested area on an island off the coast of Prince Edward Island was an inspired decision: "I purposely didn't settle for a location in an industrial park. I wanted staff to work in a tranquil atmosphere and be surrounded by nature." Besides the pleasant climate and the suitable surrounding waters of Prince Edward Island, 
the reasonable cost and quality of local labour also attracted Kevan: "I have discovered that Islanders generally have a very strong work ethic and are loyal to their employers" (also Shepard, 2007).

"Having lived and worked in the USA for many years, where the culture is more litigious, I agreed with my wife that we should separate our personal assets from our business", comments consultant Allen Stoolmiller. However, Allen - who owns and runs Stoolmiller Consulting - made a startling discovery: "I found myself working in an atmosphere that was so different". Islanders "are far more oriented towards volunteerism". In the small population of Prince Edward Island, "there is a much greater empathy for one's fellow human beings. There's a greater awareness of the importance of literally taking care of one another as a small community".... "Doing business with Islanders is very simple and straightforward. An awful lot is done with a hand shake and a word and a nod as opposed to written contracts."

Roman Makarski (a Polish immigrant) first set up BCD Automation in Montreal as a designer and manufacturer of state-of-the-art custom control system panels. Despite the decline in his salary, and fewer qualified support staff, Roman's reason for leaving Montreal and settling on PEI is clear: "My daughter decided to raise a child and she wanted a safe environment. She decided that PEI is the best place in the world to raise a kid, and to start a family."... Roman admits it took the better of two years to adapt to his new home, because he missed the big cities. However, he now concludes "I have a better life." After returning recently to Montreal for a visit, Roman vividly remembers: "Within five minutes I had already had enough. So many people, such a hectic tempo, it was crazy! It was simply too much for me".... Roman's contentment extends to his admiration for the personal touch afforded by the population size, particularly in the school system: "I'm so glad we moved here because of our grandchildren - they are the biggest beneficiaries. Elsewhere, you may be a number; while here, you are a person. This is the key difference I discovered."

Marilyn Yap Yu (a Filipino immigrant) and her husband Raymundo offer naturopathic medicine. They used to live in Ontario; but Prince Edward Island became the province of their choice. Marilyn says: "Our main purpose was to raise our children in a smaller place." She wanted her children to have 'a different environment'. Her advice after raising six children here?: "Honestly, after 18 years, I find P.E.I. is the best place to raise children". Marilyn appreciates the slow pace of Prince Edward Island, the scenery and the sense of security.

The transition from Boston, USA, to Launching, Prince Edward Island, was a welcome one for Danish Architect Ole Hammarlund, who likes the 'small scale' of the island and is a lead partner with an architectural firm. The Danish village Ole lived in was a stark contrast to Boston where he "never really felt at home'. Ole adds, "It wasn't that I disliked it. Boston is a beautiful city, but I never felt connected there quite the same way that I feel here." Besides that, Ole admires the physical attributes of Prince Edward Island because they "happen to be very much like Denmark. It's a very homey place for me."

Sasha and Beti Andric (immigrants from former Yugoslavia) set up GoldNET Smart Technologies as a custom programming firm which also provides website development and webhosting services. Although they miss some of the pleasures of the city life in Zagreb, amongst one million Croatians, they also appreciate the quality of life their young son, enjoys on the Island. 
The strategic choice orientation is by far the most popular option of all amongst current immigrant entrepreneurs to PEI. Unsurprisingly so, a similar strategy seems to guide the investment decisions of other technologically-inclined entrepreneurs from other parts of Canada:

"Recruiting talent is a major challenge... However, 'if we were in Vancouver, we'd be in an environment where people are constantly poaching from each other', says Deirdre Ayre, studio head at Other Ocean Interactive, a video game developer (and a newcomer to PEI from Newfoundland \& Labrador). 'When people make the choice to come to PEI, you know they've thought long and hard about it'. In two years, only 2 out of 30 employees have left the firm (Atlantic Business Magazine, 2008, p.22)... 'Many wonder why Atlantic Canada? And my response would be why not? Sure the industry is new here but the talent exists. ... The work ethic is unparalleled. ... So: combine "work hard' and 'play hard' and, in the gaming world, you have yourself a fine employee." (Other Ocean Interactive Blog, 2007)

There has also been targeted investment by the PEI Government. In 2003, the province developed a facility in downtown Charlottetown specifically designed to house new technology businesses. This was followed by a generous tax incentive scheme, including a $52.5 \%$ tax credit on production labour and a specialty labour tax credit which provides a rebate on the provincial portion of income taxes for key personnel (Other Ocean Interactive Blog, 2007).

\section{Discussion}

One must at this point acknowledge one key limitation of this study. The PEI data was not collected with an island brand exercise in mind. And so, the PEI respondents were not asked to comment on any actual or preferred PEI branding strategy. Nor were they asked any questions about how they branded their products and services, and if their branding strategies matched a more all-encompassing 'island brand' strategy. Instead, they were asked about their personal motivations and strategies for settling down as entrepreneurs, since that was the question driving that research study.

And yet, in spite of the incidental nature of the data, a number of features about PEI that are especially attractive to 'urban refugees' (e.g., Forsythe, 1980) are suggested. The results do confirm the outcomes of an earlier study, based on the responses of 320 recent immigrants to the island province, that indicated PEI as having a set of 'wonderful attributes': “... affordable housing, stunning landscape, pulsating civil society, slower tempo, easier access to provincial infrastructure, safety, ideal place to 'grow' kids, (re)connect with family" (Baldacchino, 2006a, p.76). There might appear to be a self-evident contradiction between the island's sedate tempo and provincial character on one hand, and the cosmopolitan dynamism expected by globally competitive firms on the other. There is however no such disconnect or clash in the minds of the professionally and technologically competent entrepreneurs who have deliberately and strategically set up operations on PEI. Indeed, rather than a deterrent, www.flypei.calm seems to be a significant reason behind the decision to locate on, or relocate to, 'the Island'.

This candid observation reminds us of how many successful entrepreneurs - not just immigrants but even local islanders - are actually nomads, 'glocal' citizens (after Robertson, 1995) who lead transnational lives. Their decision to spend time on (often 
small, often sparely populated) islands without any metropolitan infrastructure is a conscious one. They do want to have and exploit strong links to the big cities: these are, after all, the places where they source their clients, their highly qualified personnel, their professional training and their tertiary education. But such links do not necessarily involve living continuously in the metropole. This option is increasingly feasible in this day and age, with its more frequent air and sea links, and its dazzling array of information and communication technologies (although the soaring cost of fossil fuels may dampen its expansion). The connection of the frenzied and hip urban with the refreshing and humane rural is maintained via an ongoing circulation and mobility (e.g., Saxenian, 2002; Schmitt and Soubeyran, 2006). Today's 'lifestyle entrepreneurs' are after a quality life experience and a work-family life balance that they can achieve, afford and enjoy. These are individuals who often own and operate businesses closely aligned with their own personal values, interests, and passions, and which they do not necessarily operate to maximise profits (Marcketti et al., 2006).

The tentative conclusions of this study need to be confronted with further evidence gleaned from other territories to go beyond indicative legitimacy. If, however, they are fair and plausible observations, then the governments of smaller jurisdictions may be better off promoting successful entrepreneurship by ensuring that:

- their territory has an enviable 'quality of life' infrastructure: low crime, strong and safe communities, vibrant culture, efficient bureaucracies, stable economies, affordable housing, loyal workforces, welcoming neighbourhoods, healthy lifestyles, and good quality air and water - a package that is likely to lure the right type of 'creative class' immigrants (Florida, 2003; also Baldacchino, 2005b)

- their citizens enjoy sufficient and inexpensive opportunities for engaging in overseas activities, including education and employment as well as trade fair and trade mission participation, because these are the likely sources of their ideas, agents and clients

- the costs of utilising air and sea transportation as well as information technology to remain connected with the rest of the world - such as broadband availability - are as inexpensive as possible, making their island residents as widely accessible and as easily 'plugged in' as possible (Baldacchino, 2008, p.198).

This discussion takes us back to the commentary about successful island brands. The notion of developing island-specific brands that piggy back freely on 'the island allure' is not just a 'good value for money' approach to marketing, or just one that allows the development of viable export-oriented products. There is a feedback loop in place here, and the distinct aura surrounding specific products should collectively resonate harmoniously with the image that 'the Island' wants to promote about itself. The easiest such image, and the one that most 'warm water' islands have now embraced and adopted, is that of a zesty, fun-loving location, targeted at tourists. Products that accompany, and reinforce, this branding exercise include reggae, sauces and rums from the Caribbean (Pounder, 2010; Punnett and Morrison, 2006.) Islanders in colder locations, unable to develop sun, sea and parties as tourist products, have done just as well - if not better, from a long-term sustainability perspective - with messages that emphasise either clean and unspoilt spaces ripe for nature based adventure and discovery, as well as encounters with unique historical episodes, again mainly targeting tourists (Baldacchino, 2006b). Products that accompany, and reinforce, this branding exercise include whiskey from the 
Scottish Isles (Delves, 2007); Cloud Juice from King Island, Tasmania, Australia (Khamis, 2010); steel knives from Kinmen Island, Taiwan (Zhang, 2010), and 1982 war memorabilia from the Falkland Islands, a UK Overseas Territory (Royle, 2006). But neither of these two particular waves of branding efforts - as well as others that are much more generic ${ }^{4}$ - connects readily with what lifestyle entrepreneurs are necessarily looking for. Indeed, 'the Island charm' seems to have been addressed particularly at short-term visitors, not potential residents or businesspersons. When island, or mainly island, jurisdictions - like Newfoundland and Labrador - start referring to the quality of life on their island as 'their best guarded secret' or a 'secret waiting to be discovered', then they may actually be admitting that they had themselves failed to understand that their place has, or may have, a certain 'draw' that goes beyond a brief sojourn (e.g., Trip Advisor, 2006). An island is not just a 'space of flows' (after Castells, 2002), a platform for the rapid circulation of (preferably high spending) guests. We should not be surprised that many non-islanders who eventually settle on islands would have first visited their future island home as vacationers.

At the same time, though, we must remember that one cannot become a Prince Edward Islander. Island residents are loath to encourage newcomers to come, settle and take over their own characteristics. The fear of invasion, and the suspicion of 'the other', manifests itself in various forms. Displays of xenophobia, banal nationalism, cultural idiosyncrasies, tight social bonding, superficial welcoming dispositions, even the invention of tradition, can be seen as attempts at reclaiming space that is otherwise felt to be fragile and susceptible to invasion and adulteration. Islanders the world over get nervous when those who 'come from away' do not just come for a visit, but overstay (Baldacchino, 2010).

\section{Conclusion}

So: what about island branding? It appears that I/island branding exercises are advised to best focus on 'quality of life' issues, since they appear to provide the appropriate combination that can lure entrepreneurs over and provide valid experience-based reasons for not going elsewhere. If tax holidays are the catalyst to securing certain types of entrepreneurs, then these are likely to relocate as soon as the tax holiday is over: such entrepreneurs are more likely to have been lured by such fiscal considerations (such as taxes, wage bills, insurance, property costs, ...) than more enduring, qualitative ones.

Moreover, there do not appear to be any differences in life-style choices and orientation between nature-based and driven businesses and those that are more technologically/IT oriented, even though the latter would be more concerned with the nature of communications infrastructure and the availability of skilled labour. Although the option to become entrepreneurial may have been hatched for diverse reasons, the appreciation for quality of life issues on Prince Edward Island is common to all sub-sets, and probably also connects immigrants with other islanders who appreciate that they have the option to live elsewhere as back-up. This observation may apply to groups on other islands.

Nurturing an island brand that reinforces the local, quality aspects of island living - and having any distinct island product brands connect and conform to this stance - may be a superior strategy to follow than the more traditional one that considers a branding exercise as intended mainly or exclusively for an international, often tourist 
consumer, and one where the product brands could overpower the Island's 'hard core', quintessential qualities. Within the context of brand consolidation, it is perhaps the 'island way of life' attributes which should lead branding exercises, while the specific island product brands should follow. However, the trouble with this approach could be that the basics of 'island life' can be easily seen as more or less the same for the various cold water islands like PEI.

Finally, the purpose of the brand includes an emphasis on lifestyle entrepreneurship; however, other features of island life will make it difficult for immigrants, including immigrant entrepreneurs, to settle in and settle down as members of the island community. With each additional immigrant, the island community may become less trusting and welcoming of those who 'come from away'. And so, advertising 'the island way of life' may only bring about limited success. To the relief of the locals, various island immigrant entrepreneurs may find themselves moving on.

\section{Acknowledgements}

I gratefully acknowledge the support of the Åland International Institute for Comparative Island Studies (AICIS) in supporting my travel to Mariehamn, Åland Islands, during June 2008, also with a view to present this paper. My thanks also extend to the University of Prince Edward Island and the Population Secretariat of the Provincial Government of Prince Edward Island for supporting the study Profiling Immigrant Entrepreneurs on PEI (2006-2008). Thanks also to Adam Grydehøj, Anne-Marie Søderberg and Sara Underwood for useful comments on an earlier draft. I also acknowledge the extensive research support of Crystal McAndrew Fall.

\section{References}

Atlantic Business Magazine (2008) 'Plugged in, powered up', March-April, pp.21-23.

Baldacchino, G. (2005a) 'Successful small scale manufacturing: a comparative assessment across five European island regions', Bank of Valletta Review (Malta), No. 31, pp.17-31.

Baldacchino, G. (2005b) 'The contribution of "social capital" to economic growth: lessons from island jurisdictions', The Round Table: Commonwealth Journal for International Affairs, Vol. 94, No. 378, pp.35-50.

Baldacchino, G. (2006a) Coming to, and Settling on, Prince Edward Island: Stories and Voices - A Report on a Study of Recent Immigrants to PEI, University of Prince Edward Island for the Population Secretariat, Provincial Government of Prince Edward Island, Charlottetown, Canada.

Baldacchino, G. (2006b) Extreme Tourism: Lessons from the World's Cold Water Islands, Amsterdam: Elsevier Science.

Baldacchino, G. (2008) 'Entrepreneurship in smaller jurisdictions: appraising a glocal elite', Comparative Education, Vol. 44, No. 2, pp.187-201.

Baldacchino, G. (2010) 'Come visit, but don't overstay: critiquing a welcoming society', International Journal of Culture, Tourism and Hospitality Research, Vol. 4, forthcoming.

Baldacchino, G. and McAndrew Fall, C. (2008) Profiling Immigrant Entrepreneurs, Provincial Government of Prince Edward Island, Charlottetown. 
Baum, T.G. (1996) 'The fascination of islands: the tourist perspective', in D. Lockhart and D. Drakakis-Smith (Eds.) Island Tourism: Problems and Perspectives, London: Pinter, pp.21-35.

Baum, T.G., Hagen-Grant, L., Jolliffe, L., Lambert, S. and Sigurjonsson, B. (2000) 'Tourism and the cold water islands of the North Atlantic', in G. Baldacchino and D. Milne (Eds.) Lessons from the Political Economy of Small Islands: The Resourcefulness of Jurisdiction, Basingstoke: Macmillan, pp.214-229.

Castells, M. (2002) 'The space of flows', in I. Susser (Ed.) The Castells Reader on Cities and Social Theory, Oxford: Blackwell, pp.310-362.

Dahl, A.L. (1996) The Eco Principle: Ecology and Economics in Symbiosis, London: Zed.

De Bono (2007) 'Interview: Edward de Bono eyes national competitiveness', The Sunday Times Business Supplement, Malta: Progress Press, 7 January, p.82.

Debattista, M. (2007) 'The smart island in the making', I-Tech Supplement, The Times of Malta, Malta: Progress Press, 6 December.

Delves, S. (2007) Scotch Whiskey: The Story of Scotland's Greatest Export, London: Cyan Books.

Florida, R. (2003) The Rise of the Creative Class: And How It's Transforming Work, Leisure, Community and Everyday Life, New York: Basic Books.

Forsythe, D.E. (1980) 'Urban incomers and rural change: the impact of migrants from the city on life in an Orkney community', Sociologia Ruralis, Vol. 20, No. 1, pp.287-307.

Government of PEI (2008) Island Prosperity: A Focus for Change, Charlottetown PEI, Office of the Premier.

Grydehøj, A. (2008) 'Branding from above: generic cultural branding in Shetland and other islands', Island Studies Journal, Vol. 3, No. 2, pp.175-198, http://www.islandstudies.ca/ sites/islandstudies.ca/files/ISJ-3-2-2008-Grydehoj.pdf.

Hirczy, W. (1995) 'Explaining near universal turnout: the case of Malta', European Journal of Political Research, Vol. 27, No. 2, pp.255-272.

Hollingham, R. (2007) 'Environmentalists in uproar as Iceland pays the price for Green energy push', The Independent on Sunday, 21 March, http://www.independent.co.uk/environment/ environmentalists-in-uproar-as-iceland-pays-the-price-for-green-energy-push-441141.html.

Khamis, S. (2010) 'An image worth bottling: the branding of King Island Cloud Juice', Int. J. Entrepreneurship \& Small Business, Vol. 9, No. 4, forthcoming.

King, R. (1993) 'The geographical fascination of islands', in D.G. Lockhart, D. Drakakis-Smith and J.A. Schembri (Eds.) The Development Process in Small Island States, London: Routledge, pp.13-37.

Knudsen, T.R., Finskud, L., Tornblom, R. and Hogna, E. (1997) 'Brand consolidation makes a lot of economic sense: but only one in five attempts succeeds', The McKinsey Quarterly, No. 4.

Leseure, M. (2010) 'Exploitation versus exploration in island economies: a brand diagnostic perspective', Int. J. Entrepreneurship \& Small Business, Vol. 9, No. 4, forthcoming.

Marcketti, S.B., Niehm, L.S. and Fuloria, R. (2006) 'An exploratory study of lifestyle entrepreneurship and its relationship to life quality', Family and Consumer Sciences Research Journal, Vol. 34, No. 3, pp.241-259.

Martin, D. (1989) Romancing the Brand: The Power of Advertising and How to Use It, American Management Association, New York.

McClelland, D.C. (1987) 'Characteristics of successful entrepreneurs', Journal of Creative Behaviour, Vol. 21, No. 3, pp.219-233.

National Geographic (2006) 'Destinations rated: islands', http://www.nationalgeographic.com/ traveler/features/islandsrated0711/islands.html\#.

NISSOS website (2007) 'Small business from small islands: the NISSOS project', http://www.islandstudies.ca/smallbusiness.html. 
Noorani, N. and Noorani, S. (2008) Arrival Survival Canada: A Handbook for New Immigrants, Toronto, Ontario: Oxford University Press.

Other Ocean Interactive Blog (2007) http://www.otherocean.com/blog.html.

Pounder, P. (2010) 'Branding: a Caribbean perspective on rum manufacturing competitiveness', Int. J. Entrepreneurship \& Small Business, Vol. 9, No. 4, forthcoming.

Punnett, B.J. and Morrison, A. (2006) 'Niche markets and small Caribbean producers: a match made in heaven?', Journal of Small Business and Entrepreneurship, Vol. 19, No. 4, pp.341-354.

Robertson, R. (1995) 'Glocalization: time-space and homogeneity-heterogeneity', in M. Featherstone, S. Lash and R. Robertson (Eds.) Global Modernities, London: Sage, pp.25-44.

Royle, S.A. (2001) A Geography of Islands: Small Island Insularity, London: Routledge.

Royle, S.A. (2006) 'The Falkland Islands', in G. Baldacchino (Ed.) Extreme Tourism: Lessons from the World's 'Cold Water' Islands, Oxford: Elsevier, pp.181-192.

Saxenian, A.L. (2002) 'Brain circulation: how high-skill immigration makes everyone better off', The Brookings Review, Vol. 20, No.1, pp.28-31.

Schmitt, N. and Soubeyran, A. (2006) 'A simple model of brain circulation', Journal of International Economics, Vol. 69, No. 2, pp.296-309.

Shepard, S. (2007) 'Manufacturing company in Rural Kings County is expanding', Employment Journey (PEI), Vol. 9, No. 10, p.1.

Stratford, E. (2008) 'Islandness and struggles over development: a Tasmanian case study', Political Geography, Vol. 27, No. 2, pp.160-175.

Streeten, P.P. (1993) 'The special problems of small countries', World Development, Vol. 21, No. 2, pp.197-202.

The Economist (2006) 'Marketing New Zealand: from fantasy worlds to food', London: The Economist Newspapers, 11 November, p.73.

Trip Advisor (2006) 'Canada's best kept secret ... Newfoundland', 28 May, http://www.tripadvisor .com/GoListDetail-i2696-Canada_s_best_kept_secret_Newfoundland.html.

Tuan, Y-F. (1990) Topophilia: A Study of Environmental Perception, Attitudes and Values, 2nd ed., New York: Columbia University Press.

Weale, D. (1992) Them Times, Institute of Island Studies, University of Prince Edward Island, Charlottetown, Canada.

Zhang, J.J. (2010) 'Brand(ing) Kinmen: a tourism perspective', Int. J. Entrepreneurship \& Small Business, Vol. 9, No. 4, forthcoming.

\section{Notes}

1 The tension between 'the modernisers and the traditionalists' is also explored by Grydeh $\varnothing \mathrm{j}$ (2008) in the case of Shetland.

2 The mean market cost of a residential dwelling on PEI (before taxes) was Can $\$ 134,295$ in June 2007 according to the Canadian Real Estate Association: the lowest in Canada. (The highest mean was registered in British Columbia with $\$ 446,893$.) See Noorani and Noorani, 2008, Chap. 7.

3 The www.flypei.calm theme was integrated across all marketing communications by the Charlottetown Airport Authority since 2006. See http://www.sharpgrp.com/portfolio2.html.

4 The brand descriptions consulted by Leseure (2010) include a number of specifications about the feel, or personality, of islands. For example, Skye is 'breathtaking', and Orkney is 'calm', 'timeless', and 'irresistible'. Guernsey is 'contemporary' and 'thriving', Jersey is 'enriching', and the Isle of Man is 'intriguing'. The Turks and Caicos are 'beautiful by nature' while Bornholm is the bright green island. 